\title{
Urban Planning Challenges in the Peripheral Areas of Durres City (Porto Romano)
}

\author{
Sonila Xhafa, PhD. \\ Geography Department, Faculty of History and Philology, \\ University of Tirana, Albania \\ Blerina Hasani, Ma. \\ Geography Department, Faculty of History and Philology, \\ University of Tirana, Albania
}

Doi:10.5901/mjss.2013.v4n10p605

\begin{abstract}
In this paper will analyze the problems of urban development and challenges of territorial planning, mainly in the peripheral areas whichprovide comfortable conditions for strong investment in building large economic facilities, such as industrial parks, major shopping centers, other manufacturing activities, etc., which are part of the new spatial development on the northern edge of Durres. Object of study will be peripheral area of Porto Romano in Durres city, one of the most important urban centers in the country. Porto Romano lies to the north of the city of Durres, about $7 \mathrm{~km}$ from its center. Before 1990, about $50 \mathrm{ha}$ develop Chemical Enterprise activity, consisting of pesticide, sulfur and sodium factory After 1991, Porto Romano and abandoned industrial areas were assessed as environmental disaster, with risk in human health and in environment in general, especially after strengthening residential function during transition developed in informal forms. These spontaneous and uncontrolled developments of territory have made necessary the construction of territorial planning projects of this space and orientation of this territory towards sustainable development through the restoration of a better balance between public and private goods, natural and human environment, economy and natural resources. All these issues will be carefully analyzed in terms of giving directions for an urban planning in the service of the community, the environment and regional economy.
\end{abstract}

Keywords: Urban Planning, Peripheral areas, environmental issues, human risks etc.

\section{Introduction}

Territory planning studies evaluated as a necessary development instrument and emergency need primarily in urban centers affected by the spontaneous and informal development of transition, characterized by sudden demographic growth and unplanned use of territory.

Previous studies in this area are presented in the form of development strategies at regional and local level as:

- Strategic regional program funded by UNDP, Regional Development Strategy of Durres City (2005), contains the objectives of the Millennium Development

- INTERREG IIIA Programme, ANCONAPACO focused throughout the coastal area of Durres to compare the dynamics of Albanian coastal settlements with Italian coastal settlements (Marche region) and to suggest common policies in the rehabilitation of these areas, including Porto Romano;

- Important publications in terms of geographical and economic analysis of the Durres as: Towards sustainable development of Tirana-Durres region, Ecological and Regional Development Institute of Dresden (IOER), etc.

This study focuses on:

- non-integrated spaces where there is a distinct lack of basic services and infrastructure that dictate the growth of social exclusion.

- ex industrial and manufacturing space, abandoned and partially degraded carrying inherited environmental pollution;

This paper intended to provide a strategic base built on some conclusions and suggestions for sustainable use of space and regulation of urban territory in the area of Porto Romano, in support of:

- preparation of a local planning program in service of sustainable use of the territory on the basis of good management of natural and human resources (land, air, water, coastline, forests, landscapes); 
- development of a strategy for recovery and urban regeneration of area;

- urban planning process in general for the city which is still unfinished and is facing a number of legal and territorial conflicts.

Analysis of economic typology of territory and inter-linking analysis of environmental and infrastructure of the area of Porto Romano is important in service of realizing a regional unified and consolidate economic system.

\section{Geographic Position}

City of Durres is a coastal town and lies to the west of the country. This city is one of the most important urban and economic centers of the country. Urban area based on the multiple use of territory, has won important functions and intensive use of territory, becoming one of the most developed region in the country.

Durrësi is one of the most important nodes of transport in the country. Through this city cross and develop the most important national and international road axes and maritime links as: East-West Corridor $(262 \mathrm{~km})$, part of the panEuropean Corridor VIII, North-South Corridor, 405 km (Hani i Hoti-Tirana-Durres, Vlora, Saranda- Greece / DurresGjirokastra-Kakavija / Durres-Greece), and Durres-Kukes-Morine (180 km), connecting the country with Kosovo. ${ }^{1}$

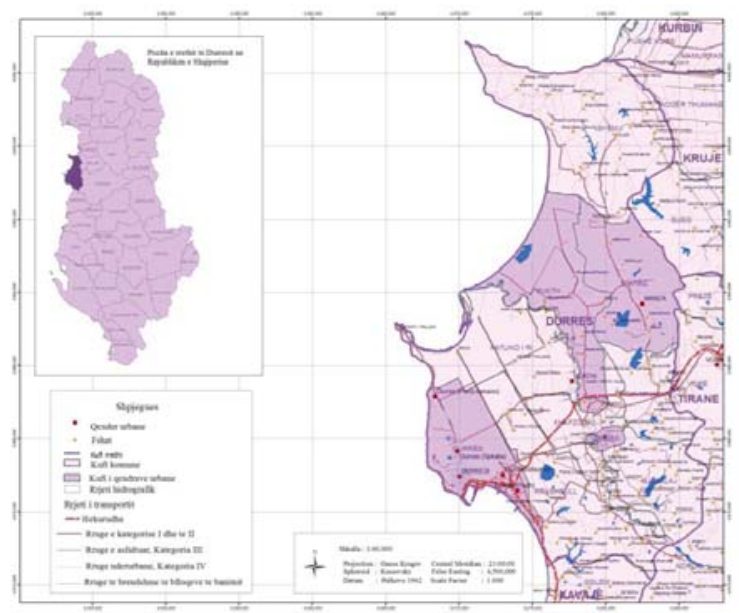

Map 1: Geographical Position of Durres City

In the city of Durres is situated the Port of Durres, the most important node of maritime transport in the country. The port of Durres is also the main line of Corridor VIII and one of the most important of gas and oil lines of Adriatic-Black Sea itineraries.

The area outside the city or suburbs includes 8 and 15 quarters (in the north), 13 and 14 quarters (part of region 6). In this area live about 59293 inhabitants ${ }^{2}$ or $29.1 \%$ of the population of the city of Durres. It is often labeled as informal city. Part of it, is industrial city and Porto Romano (with Energy Park in the north) and the coastal part (court 13). Porto Romano area lies:

- in north of Durres and $7 \mathrm{~km}$ from its center and port.

- $9 \mathrm{~km}$ from the highway linking Tirana with Durres.

Porto Romano bordered to the north by Bisht Palla, to the south by Durres city, to the east by Shen Vlash and Rrashbull hills and to west by the Adriatic Sea.

Porto Romano is about $2.2 \mathrm{~km}$ coastline ${ }^{3}$. Coastal and marine space constitutes an important natural offer, with significant impact on the development of tourism and maritime transport. Attractive and recreation landscape created by capes and rocky peninsulas, hilly forest systems valued as important assets for natural and cultural tourism. One important natural and ecological resource is the Adriatic Sea which is an interesting ecosystem. Rich marine fauna and

\footnotetext{
${ }^{1}$ Abazi A., Sfidat e transportit rrugor shqiptar ( Monografi ), Tiranë 2004.

${ }^{3}$ Directory of Statistic, Durres Prefecture.
} 
gastronomy is important in favoring opportunities for tourism development in the region, offering different types of products.

Residential function of the area was developed with the free movement of population after 1992, under favorable conditions that had Durres Region in terms of human development.

\section{The history of urbanization and industrialization}

Since the establishment of a thousand-year-old city, Porto Romano area represented a significant part of Durres, with were consolidated commercial and transit functions. For this probe a number of historic and archaeological objects in the area, such as: The wall of Porto Romanes (IV century BC), Venetian Canal near the port area, Emporioni area, the prehistorik location of Bisht Palla etc.
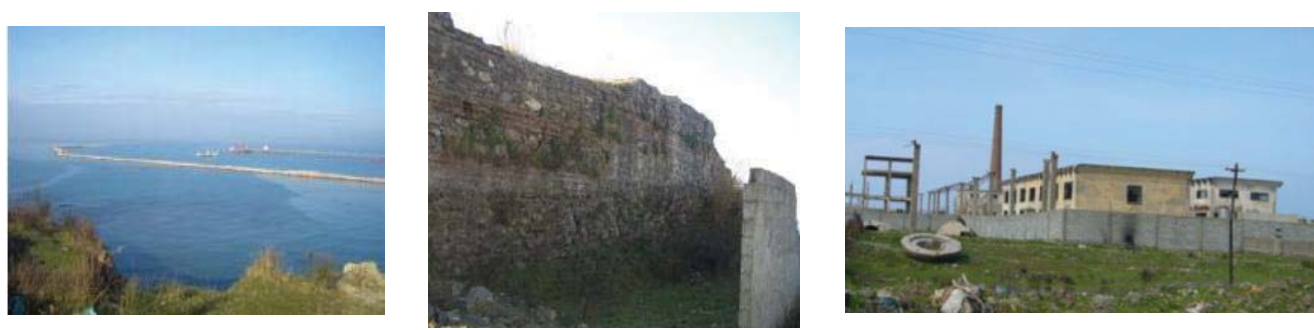

Photo 1: The coast of Porto Romano, Wall archaeological and Chemical Enterprise

City of Durres, but also the residence of Porto Romano was at the intersection of important trade routes and was the center of the first commercial center in the eastern Adriatic coast. Since ancient times, the coast of Durres has been a major factor for the population in the region. In the northern part of Durresi Hills found archaeological remains of Porto Romano, which functioned as a port at the time of the Roman Empire.

In addition, during the communist regime Porto Romano area took consolidated industrial functions. In this space has developed its industrial activity undertaken by Durresi chemical Enterprise with sectors of productuin of pesticides, sulfur and sodium bicarbonate. Another part of the enterprise used for the production of aluminum sulphate. This activity produced 20000 tonnes of toxic waste in the territory of the enterprise, mainly lindane and chromium 6 valent.

After 1990, with the closure of chemical activity, Porto Romano lost its economic functions. It was developed in typical conditions of an environmental hot spot, since for a long time pesticides and chemical residues were able to free and very close to the new residential center, created after 1995 by migrants mainly from northern areas Albania.

Free movement of population, supported the population of the area in informal conditions and the inclusion of this space into a stage against urbanization given the serious environmental problems that it inherited from the development of industrial activity, and the lack of physical and social infrastructure, which was so necessary to serve this new community.

About 300-400 $\mathrm{m}$ from the chemical enterprise lies areas inhabited mainly by migrants. In this area until hilly area are about 2300 informal housing, which occupy an area of 266 ha $^{4}$.

Currently the residential function of the area has increased, in parallel with the new infrastructure investment in the area.

\section{Environmental issues in the hot spot of Porto Romano}

After 1991, Porto Romano and abandoned industrial areas were assessed as environmental disaster, with risk to human health and in the environment in general.

Realities that produce pollution in Porto Romano are:

${ }^{4} \mathrm{ALUIZNI}$ 


\subsection{Ex Chemical Enterprise}

With the closure of the Chemical Enterprise was left unable to free many toxic substances, mainly lindane and chromate and sodium residues. All buildings and physical infrastructure that was related to industrial activity was left unable to fleeing and in the absence of full rehabilitation. Warehouses of chemical activity until 1990, deposited about 370 tons of chemicals. During the first decade of transition in these environments were able to free around 500 tonnes of lindane.

Results that pollution has gone beyond Erzeni estuary. In the east of bichromat and lindane area, a water drainage system leads to a main channel in which they join Durres wastewater. From here the waters go to a pumping station in Porto Romano and then flow into the Adriatic Sea.
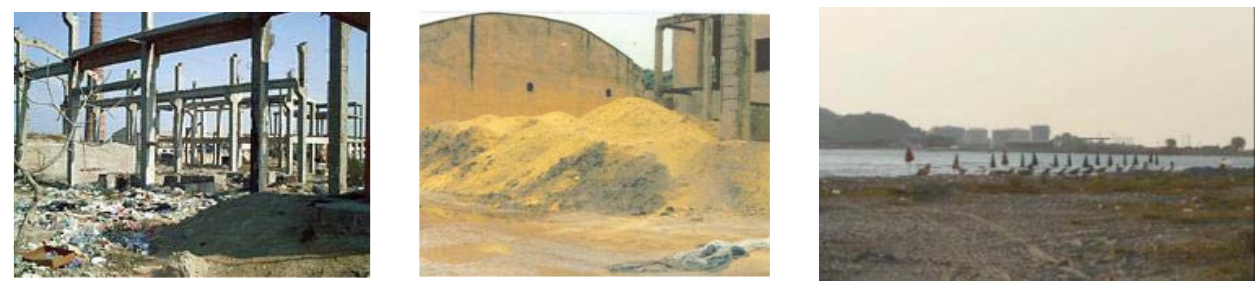

Photo 2 : Ex Chemical Enterprise, Lindan Deposits and Coastal Area

Based on measurements made on the assessment of pollution, previous studies classify the area of Porto Romano in four categories that distinguish the following characteristics.

Table 2: Polluted area classification

\begin{tabular}{|l|l|}
\hline Pollution areas & Pollution indicators \\
\hline Sulfur areas near chemical enterprise & $\begin{array}{l}\text { Observed higher concentrations in the mass 20 times higher than } \\
\text { the critical value of } \mathrm{HCH} \text { and } 270 \text { times higher than the critical } \\
\text { value of lindane prescribed for rehabilitation activities }\end{array}$ \\
\hline Lindane Area / Bichromat and pesticides & $\begin{array}{l}\text { Observed values with the highest contamination with } \mathrm{HCH} \mathrm{/} \\
\text { Lindane and Chrome }\end{array}$ \\
\hline Network channels drainage & $\begin{array}{l}\text { Observed values with the highest contamination with } \mathrm{HCH} \mathrm{/} \\
\text { Lindane and Chrome }\end{array}$ \\
\hline Waste storage warehouses of Bisht Palla & $\begin{array}{l}\text { to a diameter of about } 100 \text { square meters of warehouse-center, } \\
\text { pollution enters } 100 \text { m depth. }\end{array}$ \\
\hline
\end{tabular}

Pollution in Porto Romano is distributed in all its vital areas. Land, water and air resulting loaded with toxic pollutants.

\section{Contamination of soil:}

- has spread beyond Rinia and Bisht Kamez village

Risks:

- Contamination of vegetation, because not fed with fertilizer of different organic material, but with lindane, bichromat and sodium residues.

- Households owning livestock like cows, goats, sheep, etc., which feed on contaminated land of enterprise.

- Health problems in children who play in contaminated soil.

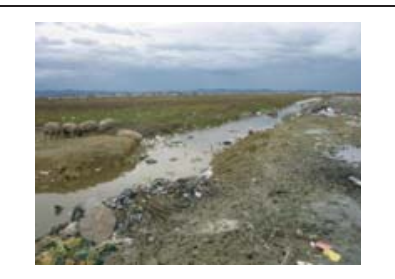


Contamination of groundwater:

- Groundwater have higher levels of $\mathrm{HCH}(2-47 \mu \mathrm{g} / \mathrm{L}$ ) and chromium (50 to $28.300 \mu \mathrm{g} / \mathrm{L}$ ) in the upper aquifer.

- Water wells are contaminated with visible presence of lindane. Analysis of well water, show that it contains 4,000 times more chlorobenzene from the acceptable level for drinking water in some EU countries ${ }^{5}$.

Risks:

- Use of water to these wells for livestock and irrigation, reduces the quality of agricultural and livestock products.

- Health problems in the community. Continuous exposure to large amounts of chlorinated benzene, causes problems in the nervous system, liver, kidneys, blood and reproductive organs

Contamination of surface waters:

- Surface water have high levels of chromium in the amount of $41-484 \mu \mathrm{g} / \mathrm{L}$. Risks:

- Damage to biodiversity

- Loss of the values of the coast and sea as tourist assets. Studies of World Bank concludes that the area Porto Romano-Bisht Palle can not be used for purposes of tourism. At a minimum area of $500 \mathrm{~m}$ in the north and $500 \mathrm{~m}$ south of the point of discharge to drainage canal that flows into the Adriatic should not allow the development of tourism.

Air pollution:

- In the air feels the strong smell of chemicals

- The number of families living in houses built with bricks contaminated, taken from buildings where previously produced lindane, is significant.

\subsection{Landfill of Porto Romano}

Since 1994, Porto Romano Landfill, is the only place for waste disposal in Durres city. It localizes about 4-5 km in north of Durres and covers an area of 200000 m2.
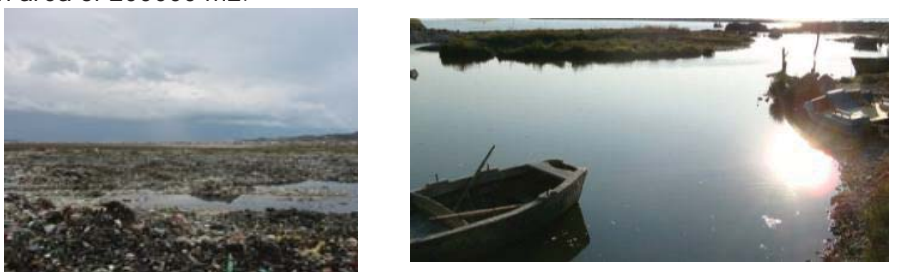

Photo 3: Porto Romano Landfill and Wetland Area

Risk factors and reasons why it should be closed this landfill are:

\footnotetext{
${ }^{5}$ Department of Public Health. Durres
} 
- Located in an environmentally sensitive area, a wetland that often flooded during the rainy season.

- Situated close to $20 \mathrm{~m}$ north of the pumping station and the point of discharge of the main channel in the Adriatic

- Its capacity is valid for 5 years. 2 of 3 parcels are filled with deposits. As a result, the total capacity of the three parcels is estimated to be $1.1-1.3 \mathrm{~m} 3$. Already, nearly half of the airspace is filled and about $600000 \mathrm{~m} 3$ are still available.

- Underground area is made up of clay and mud that have a low penetrability.

\subsection{Environmental Rehabilitation of Porto Romano}

Rehabilitation of the "hot-spot" environmental constitutes a priority that demands quick solution.

The current measures for rehabilitation of the area are:

Table 3:

\begin{tabular}{|l|l|l|}
\hline Period & Institution and agency & Project \\
\hline 1997 & Italian Goverment & $\begin{array}{l}\text { Repackaging of chemicals stored in } \\
\text { warehouses of Bisht - Palla }\end{array}$ \\
\hline $2003-2005$ & $\begin{array}{l}\text { Ministry of Environment, Forestry and } \\
\text { Water Administration, World Bank }\end{array}$ & $\begin{array}{l}\text { feasibility project for cleaning and } \\
\text { rehabilitation of the area }\end{array}$ \\
\hline 2003 & World Bank & $\begin{array}{l}\text { Coastal Zone Management: Bisht Palle- } \\
\text { Durres }\end{array}$ \\
\hline 2006 & Netherlands Government & Waste Management \\
\hline
\end{tabular}

In addition to the initiative of the Ministry of Environment, it was possible to realize:

- Technological waste, mainly containing lindane and sodium bikromat, was deposited at large in a $1.5 \mathrm{~km}$ radius of the enterprise.

- 320 tonnes of chemical waste, of which 200 tons of solid waste, 100 tons of liquid waste and 20 tons of sludge held in these stores (and in Porto Romano), was pulled out of the country and were sent to be processed in a waste treatment plant.

- Storage of pesticides and waste generated by the process of lindane production, has become close BishtPalla, exactly in three stores. About 400 tons of chemicals are still stored in an area of 750 hectares.

- Construction of a capsule with an area of 20 thousand sqm for isolation of the remains of the ex chemical enterprise.

- Excavation of contaminated soil in the area of the chemical enterprise;

- Destruction of the remaining parts of the chemical enterprise, isolation of 28 thousand square meters of industrial waste from sodium and bichromate factories.

According to the Municipality of Durres, the final rehabilitation of the area will be carried out consistently with the support of the Netherland Embassy and the World Bank.

\section{New territorial developments and challenges of suistainable urbanization}

Peripheral spaces provide comfortable conditions for large investments. The low price of land and spatial access to design physical and public infrastructure increased investment in building large economic facilities, such as industrial parks, major shopping centers, other manufacturing activities, etc., which are part of new spatial developments in the northern part of Durres. Northern Suburbs offers attractive and recreation landscapes, which can be invested also for the construction of ecological and integrated parks. 


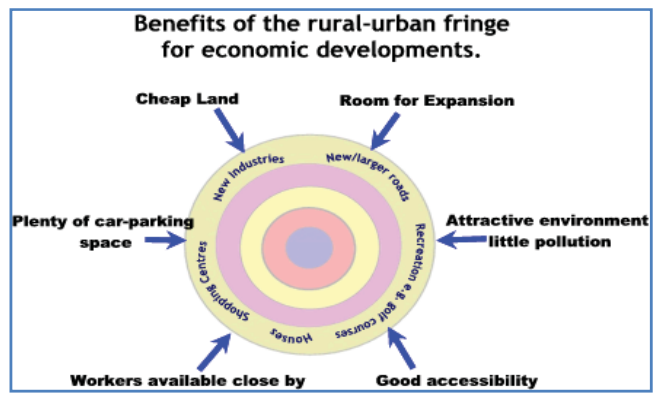

Fig. 1. Advantages provided by the periphery for economic investment ${ }^{6}$.

In the area where it is intended to build Energy Park (northwest of Durres) lives around $6.5 \%$ of the population of the city of Durres ${ }^{7}$. The park is expected to create a strong base for economic development of the city and the region, including the activation and operation of heavy industry, light industry, manufacturing and processing, construction activities, education and health services, etc.. Energitic and Industrial Park is designed to be extended to 1720 hectares.

Energy Park ${ }^{8}$ will extend about $10 \mathrm{~km}$ from the city and will occupy 810 hectares, in the space between Romano Port and Bisht Palla. This park will be built and managed by private investors, in partnership with the public sector.

\subsection{Industrial Park}

Economic Zone with the status "Industrial Park" , surrounded by oil products terminal, deposits of oil and gas, will occupy about 850 ha and will work with the status of an economic space with industrial production and agro-processing character.

Petroleum products Terminal (diesel, gasoline, kerosene, fuel) and liquid gas Terminal in Porto Romano is projected to be built in an area of 2 hectares, with length about $1100 \mathrm{~m}$. Its annual capacity is expected to be $140000 \mathrm{~m} 3$ of petroleum products and $14000 \mathrm{~m} 3$ of liquefied gas ${ }^{10}$. Deposits of oil and liquefied gas stretching around 26 hectares and have a total capacity of $140000 \mathrm{~m} 3$ of petroleum products and $18400 \mathrm{~m} 3$ of liquefied gas ${ }^{11}$.

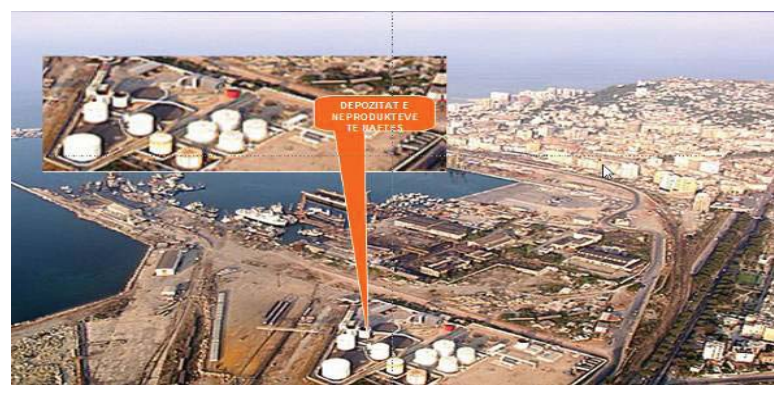

Photo 4: Deposits of oil products

It is planned that the space for industrial utilization occupy about $50 \%$ of the total planned area and the rest be used for:

a. internal support infrastructure:

- electricity network,

${ }^{6}$ Adair. A. "The Financing of urban regeneration". Land Use Policy. Vol.17. 2000.

${ }^{7}$ Author

${ }^{8}$ Approved by DCM. 703, dated 23.04.2008

${ }^{9}$ Approved by DCM. 391, dated 21.02.2008

${ }_{10}$ Chamber of commerce and industry. Durres Prefecture. Durres, a good business choice. May 2009

${ }^{11}$ Chamber of commerce and industry. Durres Prefecture. Durres, a good business choice. May 2009 
- drinking water network,

- Industrial water system,

- sewage and wastewater,

- sewage water from rain,

- network of telephone lines and Internet connections;

b. external supporting infrastructure:

- the main road network and internal network (road connecting with highway, road Spitallë-Durres, railway Durres-North Sukthi-)

- supporting infrastructure for services and trade,

- infrastructure for recreation and green.

In order to better use and management of industrial economic space, required to be categorized this space according to its function and typology, respectively:

- industrial space

- promotion space

- logistical and infrastructure space

Also, to increase productivity and to close with each other the center of agricultural production and the industrial processing center, it is necessary to plan an intermediate space around the industrial area, for agricultural use, being classified as areas of urban agriculture.

\subsection{Romano Port}

Romano Port has built $6.5 \mathrm{~km}$ north of the city of Durres. This port is planned for Imports of oil and LPG and for completion of term deposits of oil at the port of Durres. The the expansion of the existing of Romano port will continue in the northern part of the Container Terminal
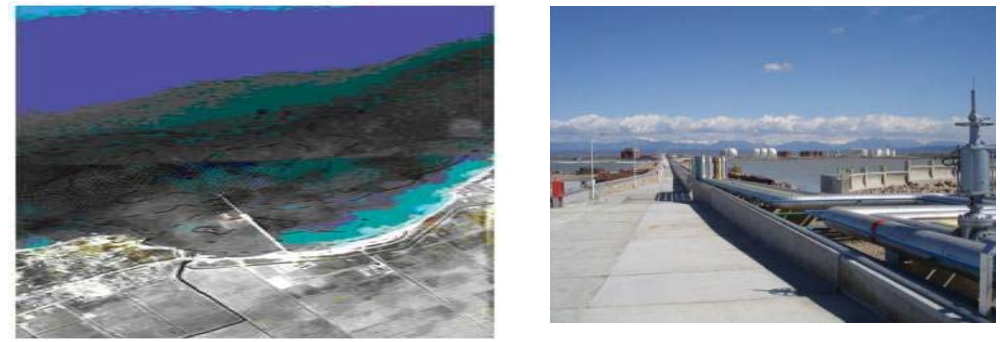

Photo 5: Romano Port

\subsection{Territorial Park}

This park is planned to be built in the area of Kallmi, since it possesses recreational landscapes. Territorial Park will support industrial activity in terms of minimizing the pollution and will connect the coast with hilly area and northwest.

It is designed to be built as a free natural park overlooking the sea and integrated with public facilities in terms of service and entertainment, such as bars and restaurants, free markets, parking spaces etc.

According to data in Durres municipality, this project:

- provides standards for green and contributes to improving the quality of life of residents.

- contains strict limits regarding new constructions.

According to estimates of social, economic and environmental issues associated with building of Energy-Territorial Park results that:

- Its construction will generate opportunities employment, economic growth, increased living standards etc. It is expected to employ about 42000 people, that is converted to 5250 more flats in the following 10 years ${ }^{12}$. Thus, the area will have a new breath in demographic terms.

${ }^{12}$ Chamber of commerce and industry. Durres Prefecture. Durres, a good business choice. May 2009 
- construction of the park will encourage further investment to cover the area with full physical and social infrastructure, enabling rapid integration of local community with the city center;

- ndërtimi i parkut do të gjenerojë përfitime ekonomike rajonale dhe kombëtare;

- it is conceived and designed as an eco-park, where economic activity reports with environment will be friendly.

\section{Conclusions:}

Periphery of the city will continue to be affected by spatial transformations, dictated by rapid rate of the economic development in the future. Despite informal developments, periphery is one of the potential areas of economic development. It should be appreciated as an important production area in support of urban development.

\subsection{Alternatives to urban regeneration and regulation of territory}

Objective 1: Categorization of Porto Romano as reclamation and environmental restoration space (Hot Spot) and as strategic planning space to support new developments eco-industrial (Port of Porto Romano).

Objective 2: Evaluation of the area as a potential development space primarily in terms of its full coverage with all physical infrastructure necessary for its integration with the city center.

A. Taking remedial interventions in the road axis connecting Porto Romano (new industrial city) port and the central city area.

B. Integrated Connection of new planned infrastructure facilities with existing facilities in order to develop this park within a key point communication that connects and integrates two ports, railways and major road corridors.

C. Physical, functional and infrastructure Integrating between existing residential informal settlements and new industrial park

Objective 3: Integrating Energy Park plan with general urban plan of the city, setting exatly: plot ownership (municipal, state, private, ambiguous), roads and service networks, informal space,current space for industrial production, potential spaces designed for industrial purposes, green spaces, intermediate spaces (buffer zone ) etc.

Objective 4: Classification of the area as a space of continuous monitoring and environmental conservation with special attention to the effective management of waste by modern recycling technologies.

Objective 5: Forecasting the needs of social and physical infrastructure development in the future on the basis of demographic growth forecasts.

\section{References}

Agjensia Kombëtare e Mjedisit, Raport për gjendjen e mjedisit 1997-1998, Tiranë 1999, 2000, 2001.

Axhemi S., Gjeografia e Popullsisë dhe e Vendbanimeve, Tiranë 2007.

Axhenda Institute, SWOT Analysis for the Sustainable Economic Development of the City of Durrës, June 2008.

Effects of pollution on the environment and health in the area of Porto Romano, Ministry of Environment, Forests and Water Management of Albania, March 2005.

General Guidelines for the Preparation and Reviewing of Environmental Impact Assessments 2004.

Deben L., Culture and urban regeneration: some European examples, 1992.

Dhoma e Tregëtisë dhe Industrisë, Durrësi, një zgjedhje e mirë bisnesi, Tirane 2009.

Laçi S., Gjeografia Rurale, Tiranë 2006.

Laçi S., Xhafa S., Gjendja e mjedisit në rrethin e Durrësit, Acta Lingua Geographica 3, Shkup 2007.

Laçi S., Xhafa S., Klasifikimi dhe drejtimet e zhvillimit të hapësirave rurale të Shqipërisë, Kërkime gjeografike, Prishtinë 2008.

Landell Mills Development Consultants, Rapid Environmental Assessment for the Industrial and Energetic Park's at Porto Romano, Durrës, Albania, May 2008Law 9298/2004 On Ratification of the Concession agreement of BOT type, for Construction and Exploitation of an Oil and its Products Pipeline in the Coastal Area of Porto Romano;

Pranvera Dokle, 2008. Study on Geo-Engineering Conditions of the Area of Construction of Energetic and Industrial Park of SpitalleDurres, Albanian Geological Survey, Tirana.

Report from the EU project: "Sustainable and Integrated Development of the Tirana-Durres Region", December 2007 (SIDTDR).

Xhafa S. Development of urban centers of Durresi District, Land use and Territory regulation, October 2011, Geography Department, University of Tirana. 